\title{
Seven Remarks on the Seventh Angel
}

\section{Introduction}

\section{MICHEL FOUCAULT'S ESSAY “7 PROPOS SUR LE 7E ANGE” (“SEVEN RE-} MARKS ON THE SEVENTH ANGEL") FIRST APPEARED AS THE PREFACE TO

a bizarre work of folk etymology by Jean-Pierre Brisset (1837-1919), a stationmaster and autodidact from Angers, in the west of France. Brisset's La grammaire logique (Logical Grammar) - self-published in 1878-and its companion piece, La science de Dieu (The Science of God [1900]), remained obscure for the better part of a century, until Éditions Tchou, a press specializing in surrealist and esoteric writing, republished them together in a single volume, with Foucault's preface, in 1970.

Brisset's extraordinary argument is that the French language, far from developing over time through proto-Indo-European and Latin, has been more or less the same since the time it was first spoken in swamps by our ancestors, a violent race of cannibalistic frogs. Furthermore, clues about this first, amphibious society are encoded in the language spoken today. According to Brisset, all words or phrases that sound the same must be linked by a common origin. So if grammar sounds like grandma, this tells us something about grammar, about grandmas, and about the history of the world. In Brisset's bold dictum, "All ideas spoken with similar sounds have a shared origin and all relate, originally, to a shared object" (OEuvres 702; my trans.).

Despite being out of print for most of the twentieth century, Brisset was not exactly unknown. Rather, he had the cult status of the fou litterraire, a literary madman best known through two notable potted descriptions of his eccentricity: a chapter in André Breton's Anthologie de l'humour noir (1940; Anthology of Black Humor [1997]) and Raymond Queneau's article "La théologie génétique de Jean-Pierre Brisset" ("The Genetic Theology of Jean-Pierre Brisset"), which appeared in the journal Bizarre in 1956. Given the authors of these two pieces, it is clear that Brisset was a secret shared at the very top table of the mid-century avant-garde.

And yet Brisset was no avant-gardist. His investigations were entirely in earnest, naively oblivious to the gulf between his wild conclusions and those of the academic establishment. Like the poet and dramatist Raymond Roussel, he would surely have been bemused to learn that his work had found a
MICHEL FOUCAULT

INTRODUCTION AND

TRANSLATION BY DENNIS DUNCAN
DENNIS DUNCAN is the Munby Fellow in Bibliography at Cambridge University. He recently completed a monograph on the early years of the Oulipo and is working on a history of the book index from the Middle Ages to the present. 
receptive readership in the wryly disruptive ranks of the surrealists.

With this in mind, we should not be surprised that Brisset should have appealed to Foucault, whose monograph Raymond Roussel (Death and the Labyrinth [1987]) had appeared in 1963. Indeed, the essay on Brisset might serve as an accessible summation of Foucault's 1960s work, focusing as it does on another linguistic eccentric, a parallel, "outsider" take on an established system of knowledge and a cosmogony wholly based on the speech act. It might also be seen as a companion piece to Foucault's 1968 essay on René Magritte, Ceci n'est pas une pipe, a close examination of the Saussurean orthodoxy of the arbitrary relation between words and things. As Jean Starobinski's Les mots sous les mots (1971; Words upon Words [1979]) would reveal, Saussure himself had practiced a paranoid mode of reading not unlike Brisset's, believing that he had uncovered a system of anagrams secretly but consistently placed throughout classical Latin poetry.

Foucault's preface needs to be read not only against the background of late-1960s semiotics but also in the context of another work that appeared the same year as "7 propos"-Louis Wolfson's autobiography, Le schizo et les langueswhich Foucault engages in his essay. In the preface to Wolfson's book, Gilles Deleuze (whom Foucault quotes), describes the struggles of its schizophrenic author, growing up in New York unable to bear the sound of the English language spoken by his mother. Wolfson's extraordinary coping mechanism was to imagine that the words he heard were really a mash-up of French, German, Russian, and Hebrew syllables and to deliberately mishear every English phrase in this polyglot idiolect.

Triangulating among these three points-Brisset, Roussel, Wolfson-Foucault sketches out a comparative account of schizoid language that is, at first, patiently analytic but spins off playfully into a sexualized, anatomical grand theory every bit as eccentric, unreasonable, and compelling as the case histories it takes for its subject matter.

In the last of the essay's seven sections, Foucault abruptly reins in this creative excess and presents a handful of facts about Brisset's life. He closes with a detail withheld until the end: the "seventh angel" of the essay's title is Brisset himself, and the delusions of grandeur inherent in his extraordinary work went way beyond mere academic imposture. Foucault's depiction of the self-styled "Archangel of the Resurrection and Seventh Angel of the Apocalypse" sulking at the paltry crowd that turned out to hear his "voice of thunder" is wonderfully bathetic, and yet the essay itself is a vindication and celebration of Brisset, a classic Foucauldian critique of the institutionalized forms of knowledge against which he is pitted, "a sudden whirlwind amid so much mild delirium."

Foucault's endorsement has paid off. In the decades since the Tchou edition appeared, Brisset's star has been in the ascendent. His other works have been reprinted, culminating in 2001 in a large, single-volume collection of his complete works (OEuvres). This was accompanied by a witty but substantial biography in French by Marc Décimo, Jean-Pierre Brisset, and by Walter Redfern's Englishlanguage biography, All Puns Intended. Brisset has found a role in theories of literary nonsense (Lecercle 23-27) and of modernism (Rabaté 46-49), and he has even been the subject of a number of largescale choral works - for human voices (Les origines humaines) and for mass frog recordings (Catalogue de grenouilles) - by the composer Andrew Hugill.

Foucault quotes Brisset at length five times in "7 propos," choosing passages for the puns they contain, some of which do not easily translate from French to English. While in French, for example, doigt mien may sound something like démon (Brisset strains the homophonic relation to its limits), the simplest English translation, digit mine, isn't close enough to demon to convey Brisset's method. Standard translation practice these days might be to replace the original pun in French with a different one in English, like demon / day man. But a functional rather than semantic equivalence won't do here since Brisset's whole thesis is that sound and sense cannot be separated: in Brisset's cosmogony, demons are bound up with digits, 
not with days. We could, of course, unpack the syllables of contemporary English to produce another wild history of the world, but that would be a different exercise. A translation of Brisset must leave his puns in place, and so I have included the original French in square brackets after its translation—in this case, "my finger [doigt mien]."

Much of Brisset's punning relies on constructions that are syntactically or even lexically unusual in the original. In translating Brisset, it is often tempting to do him a favor and tidy up a little of the mangled phrasing, making the wordplay look slicker or more plausible than it is. If I have sometimes been guilty of this, I hope the payoff will have been to highlight Brisset's chains of homophonic reasoning and narrative production. Nevertheless, I have included in Brisset's French the full passages that contain his extended wordplay.

\section{NOTES}

"Sept propos sur le septième ange," text no. 37 in Dits et écrits I, Michel Foucault @Editions Gallimard, 1994. I am very grateful to Éditions Gallimard for permitting this translation to be published. I am also indebted to Christophe Wall-Romana for his generous suggestions regarding the translation; if any deficiencies remain, the fault is entirely my own.

1. “Toutes les idées énoncées avec des sons semblables ont une même origine et se rapportent toutes, dans leur principe, à un même objet."

\section{Works Cited}

Breton, André. Anthologie de l'humour noir. Sagittaire, 1940.

Brisset, Jean-Pierre. La grammaire logique ou théorie d'une nouvelle analyse mathématique résolvant les questions les plus difficiles. Paris, 1878.

—. La grammaire logique, résolvant toutes les difficultés et faisant connaître par l'analyse de la parole la formation des langues et celle du genre humain. E. Leroux, 1883 .

—. La grammaire logique, suivi de La science de Dieu. Preface by Michel Foucault, Éditions Tchou, 1970.

- Euvres complètes. Edited by Marc Décimo, Presses du Réel, 2001.

Décimo, Marc. Jean-Pierre Brisset: Prince des penseurs, inventeur, grammairien, et prophète. Presses du Réel, 2001.

Foucault, Michel. Ceci n'est pas une pipe: Deux lettres et quatre dessins de René Magritte. Fata Morgana, 1973.

- Raymond Roussel. Gallimard, 1963.

_ . "7 propos sur le 7e ange." Preface. Brisset, Grammaire logique, pp. vii-xix.

Hugill, Andrew. Catalogue de grenouilles. BMIC/Hugill, 1990.

—. Les origines humaines. BMIC/Hugill, 1995.

Lecercle, Jean-Jacques. Philosophy through the LookingGlass: Language, Nonsense, Desire. Hutchinson, 1985.

Queneau, Raymond. "La théologie génétique de JeanPierre Brisset." Bizarre, vol. 4, 1956, pp. 80-88.

Rabaté, Jean-Michel. 1913: The Cradle of Modernism. Blackwell, 2007.

Redfern, Walter. All Puns Intended: The Verbal Creation of Jean-Pierre Brisset. Legenda, 2001.

Starobinski, Jean. Les mots sous les mots: Les anagrammes de Ferdinand de Saussure. Gallimard, 1971.

Wolfson, Louis. Le schizo et les langues. Preface by Gilles Deleuze, Gallimard, 1970.

\section{Seven Remarks on the Seventh Angel}

1.

LA SCIENCE DE DIEU [“THE SCIENCE OF GOD”] and, for a good part of it, La grammaire logique ["Logical Grammar"] present themselves as studies on the origin of languages. Such traditional research, going back centuries, drifted in the nineteenth century, little by little, toward delirium. Let us take a symbolic date for this exclusion: the day the learned societies began to reject papers on the original language. ${ }^{1}$

But in this long dynasty, banished one fine day, Brisset occupies a unique position 
and plays the subversive, a sudden whirlwind amid so much mild delirium.

\section{The Principle of Nontranslation}

The foreword to La science de Dieu proclaims, "The present work cannot be fully translated." Why not? This statement ought to surprise us, appearing in a study on the common origin of all languages. Is this origin not composed-as dictated in the tradition eminently exemplified by Court de Gébelin-of a small number of simple elements linked to things themselves and remaining in trace form in all the languages of the world? ${ }^{2}$ Can we not-directly or indirectly-trace all the elements of language back to this origin? Is it not that into which any idiom can be retranslated, and does it not form a constellation of points through which all the languages of the world, current or past, communicate? It is the basic element of universal translation: other in relation to all languages, but the same in each of them.

And yet this supreme, elementary, directly expressive language is not what Brisset is driving at. He stays where he is, with and in the French language, as if it were its own origin, as if it had been spoken since the beginning of time, with the same words, or very nearly, only distributed in a different order, disrupted by metathesis, condensed or distended by dilations and contractions. The origin of French is not, for Brisset, something anterior to French; it is French at play with itself, tumbling outside itself into the ultimate dust that is its beginning.

Let us take the birth of the thumb:

this thumb $[$ pouce $]=$ this growth $[$ pousse $]$. This similarity tells us that we use the thumb [pouce] to push [pousser], when the fingers and toes have already been assigned. Push it $[$ Pous ce $]=$ Take that. We start to pick the young shoots [jeunes pousses] of grass and buds when the thumb [pouce], still young [jeune], forms itself. With the evolution of the thumb our ancestors became herbivores. [ce pouce = ce ou ceci pousse. Ce rapport nous dit que l'on vit le pouce pousser, quand les doigts et les orteils étaient déjà nommés. Pous $\mathrm{ce}=$ Prends cela. On commence à prendre les jeunes pousses des herbes et des bourgeons quand le pouce, alors jeune, se forma. Avec la venue du pouce l'ancêtre devint herbivore.]

To be honest, for Brisset there is no primitive language that corresponds with the diverse elements of any present-day language; nor, similarly, is there a particular archaic form of language from which one could derive, point by point, the way we speak now. Instead, for him, primitivity is a fluid, mobile, indefinitely penetrable state of language, a possibility of movement in every direction, a field open to all transformations, reversals, and lacerations, the multiplication-at every point, in every syllable or sound-of the powers of designation. What Brisset discovers at the origin is not a limited ensemble of simple words strongly attached to their referents but language as we speak it today-this language itself in a state of play, at the moment the dice are thrown, when the sounds are still rolling, showing their successive faces. In this first age, words tumble out of the shaker of definition only to be picked up again ceaselessly, falling anew, each time according to new forms and following different rules of decomposition and regrouping:

The demon $[$ démon $]=$ my finger $[$ doigt mien $]$. The demon shows his dice [dé], his dais [dais], or his deity $[d i e u]$, his sex.... The inverse construction of the word demon gives: my dice [mon dé] = my god [mien dieu]. World I have [monde ai $]=$ I possess the world. Thus, the demon becomes the master of the world by virtue of his sexual perfection.... In his sermon [sermon] he calls his serf: my serf [serf mon]. The sermon is a servant of the demon. Come to my bed [lit mon]: the ooze [limon] was his bed, his natural habitat. He was a strong jumper and the first of the salmon [saumons]. See my beautiful leap [le beau saut mon]. 
[Le démon = le doigt mien. Le démon montre son dé, son dais, ou son dieu, son sexe... La construction inverse du mot démon donne: le mon dé = le mien dieu. Le monde ai = je possède le monde. Le démon devient ainsi le maître du monde en vertu de sa perfection sexuelle... Dans son sermon il appelait son serf: le serf mon. Le sermon est un serviteur du démon. Viens dans le lit mon: le limon était son lit, son séjour habituel. C'était un fort sauteur et le premier des saumons. Voir le beau saut mon.]

This is language as emulsion, where words leap haphazardly, as our ancestors, the frogs, leaped in the primordial swamps, according to the laws of a random fate. In the beginning were the dice. The rediscovery of primitive languages is not the result of translation; it is the movement and repetition of chance in language.

This is why Brisset was so keen to demonstrate that Latin did not exist. If Latin had existed, we would have to track backward from living French toward this other language, different from French but from which the latter can be derived by fixed rules; and from there we would have to work back even further toward the stable state of an elementary language. In doing away with Latin, the chronological calendar disappears; the primitive ceases to be anterior; it bursts forth through all the happenstances of language suddenly reencountered.

\section{Infinite Envelopment}

When Duret, de Brosses, and Court de Gébelin sought to recover the primitive state of language, they would reconstruct a limited ensemble of sounds, words, semantic content, and rules of syntax. ${ }^{3}$ To trace the common root of all the world's languages and to rediscover it again today in each of them, it was inevitable that the elements of this idiom be relatively few and its rules of construction limited. Ultimately, at the top of the pyramid, there is but one cry-a single cry differentiated from all noise or contrasted with another articulated sound. Traditionally, the primal language is conceived of as an impoverished code. For Brisset, by contrast, it is a discourse without limits, whose description can never be completed. And this is for a number of reasons.

His analysis does not take a contemporary term and trace it back to a first element that can be found again elsewhere in a more or less disguised form. Instead, it successively explodes the word in many elementary combinations, so that its current form, when we decompose it, reveals several archaic states; these originally differed from one another but, through the play of sedimentation, contraction, and phonetic modification unique to each, have ended up converging toward a single expression that gathers and contains them all. It is the aim of the science of God to redisclose them and to make them revolve, like some great multicolored ring, around the word under analysis. Thus, for the expression in society [en société]:

In this water sit thee [En ce eau sieds-té $]=$ sit yourself in this water [sieds toi en cette eau]. In a pail sit thee [En seau sieds-té], in sauce it was [en sauce y était]; he was in the sauce, in society. The first ocean was a pail, a sauce, or a pond, our ancestors were there in society [en société].

[En ce eau sieds-té = sieds toi en cette eau. En seau sieds-té, en sauce y était; il était dans la sauce, en société. Le premier océan était un seau, une sauce, ou une mare, les ancêtres $y$ étaient en société.]

It is the opposite of the process of searching for a single root shared by several words; it amounts to allowing the anterior states crystallized in a present unit of language to proliferate. Resituated in the vast primordial soup, any current expression reveals the multiple facets that formed it, that limit it, and that, to the trained eye alone, trace its invisible geometry. 
Furthermore, the same word can pass through this analytic filter several times. Its decomposition is neither unique nor fixed once and for all. Often Brisset will take it up again, even several times; thus the verb to be [être] is analyzed sometimes in relation to to have [avoir], sometimes in relation to sex. Taken to the limit, we could imagine that each word of the language might be used to analyze all the others, that each is the agent of destruction for every other, that language in its entirety decomposes itself by means of itself, that it is its own filter and its own originary state, that it is, in its current form, the result of a game whose pieces and rules are borrowed almost exactly from this current form, which is precisely the way we speak. If we were to pass any modern word through the filter of all the others, it would have as many origins as there are words in the language-more, even, if we recall that each analysis gives several possible decompositions in an inseparable group. According to Brisset, searching for an origin does not tighten language: rather, it breaks it down and multiplies it by itself.

Finally, the last principle of proliferation: what we discover in the first state of language is not a treasure trove, nor even an abundance of words; it is a multiplicity of utterances [énoncés]. Beneath a word we utter, what is hidden is not another word, nor even several words soldered together; for the most part, it is a phrase or a series of phrases. Here, for example, is the double etymology-and let us admire the double nature of the twinning-of origin and imagination:

Water laughs [Eau rit], ore ist, oris [perhaps as in the genitive singular of the Latin os, mouth: of the mouth]. I is knot [J'is noeud; so "oris. J'is nœud," sounds like origine eau, "origin water"], source. Oris $=$ source $=$ the urine source, the laughing water source. Naked at the ridge [Au rige ist noud]. Origin. Passing water is the origin of speech. The inversion of oris is rio, and rio or water laughing is the stream [ruisseau]. As for the word gine, it is readily applied to the female [presumably as in the Greek gynē]: you grind yourself on the girl [limes à gine]? You're imagining it. I grind myself, on the girl? I imagined it. We do this and the image is born [l'image ist né]; we do this, grind on the girl, we imagined it. Grind girl in furrow; the image is knot at furrow; the image is, not the furrow.

[Eau rit, ore ist, oris. J'is nœud, gine. Oris $=$ gine $=$ la gine urine, l'eau rit gine. Au rige ist nœud. Origine. L'écoulement de l'eau est à l'origine de la parole. L'inversion de oris est rio, et rio ou rit eau, c'est le ruisseau. Quant au mot gine il s'applique bientôt à la femelle: tu te limes à gine? Tu te l'imagines. Je me lime, à gine est? Je me l'imaginais. On ce, l'image ist né; on ce, lime a gine ai, on se l'imaginait. Lime a gine à sillon; l'image ist, nœud à sillon; l'image ist, n'ai à sillon.]

Language in its primary state was not, therefore, a definable collection of symbols and rules of construction; it was an undefined mass of utterances, a trickling of things said: what we must rediscover, behind the words of our dictionary, are not morphological constants but affirmations, questions, wishes, commandments. Words are fragments of speech traced by themselves, modalities of utterances, frozen and reduced to neutrality [au neutre]. Before words there were phrases; before vocabulary there were utterances; before syllables and elementary arrangements of sounds there was the indistinct murmur of all that was said. Long before language, we were speaking. But what did we speak of, if not of that man who, not yet equipped with language, did not yet exist; if not of his formation, slowly wrenching himself from animality; if not of the swamp where, with a great effort, he escaped his tadpole existence? So that beneath the words of our language can still be heard the phrases-pronounced in the same words or near enough-of a people who did not yet exist and who spoke of their future birth. Brisset says that he will "demonstrate the creation of Man using materials that we 
will take from your mouth, dear reader, where God placed them before Man was created." This is the double and intertwined creation of man and language, against the backdrop of an immense anterior discourse.

For Brisset, to search for the origin of languages is not to find the principle of their formation in history, a game of revealing the elements underlying their construction, a universal communication network between them. Rather, it is to open each language up to unlimited multiplicity, to define a stable unity within a proliferation of utterances, to turn the organization of the system back toward the exteriority of things said.

\section{The Noise of Things Said}

Here are the captured bastards [salauds pris]; they are caught in the dirty water [sale eau pris], in the trophy room [salle aux prix]. The captured [pris] were the prisoners whom we had to butcher. While waiting for the prisoners' day, which was also prize-giving [des prix], we locked them in a room [salle], dirty water, where we threw slops [saloperies] at them. There we insulted them, we called them bastards [salauds]. The prisoner had a price $[d u$ prix]. We ate him, and, to lay a trap, we offered a prisoner $[d u$ pris $]$ and a price $[d u$ prix]: that was the prize $[d u$ prix]. It's a trick [duperie], responded the sage, don't accept the prize, dear sir, it's a trick.

[Voici les salauds pris; ils sont dans la sale eau pris, dans la salle aux prix. Les pris étaient les prisonniers que l'on devait égorger. En attendant le jour des pris, qui était aussi celui des prix, on les enfermait dans une salle, une eau sale, où on leur jetait des saloperies. Là on les insultait, on les appelait salauds. Le pris avait du prix. On le dévorait, et, pour tendre un piège, on offrait du pris et du prix: c'est $d u$ prix. C'est duperie, répondait le sage, n'accepte pas de prix, ô homme, c'est duperie.]

We can see it clearly: the task for Brisset is not a matter of minimizing the distance be- tween saloperie and duperie, to make it seem plausible that the gap might be bridged. Between one word and the other episodes swarm battles, victories, prisons and persecutions, massacres, chunks of human flesh sold and eaten, skeptical sages, crouched and sullen. The common element of the two wordspri-does not guarantee smooth passage from one to the other since it gets decoupled itself, recast several times, invested with different roles and charged with different sounds: an inflection of the verb prendre [to take], an abbreviation of prisoner, a sum of money, the value of something, a reward (as one gives out at a prize giving). Brisset does not reconcile the two words-saloperie and duperie-he aligns them with each other or, rather, he sets the space that separates them bristling with manifold events and motley, improbable figures; he populates it with the greatest possible number of differences. But neither is it a matter of showing how the word saloperie or the word duperie is formed. The first, for example, is already given almost in its entirety at the start of the game: "Here are the captured bastards [salauds pris]"; it only takes an inflection for it to be formed and brought into existence. But then it decomposes differently, nearly disappears-dirty water [sale eau], room [salle]-only to rematerialize suddenly, fully formed and charged with the sense that we give it today: "We threw slops [saloperies] at them." This is not a slow genesis, the progressive acquisition of form and stable content; rather, it is a matter of appearance and disappearance, the flickering of the word, periodic eclipse and return, discontinuous springing up, fragmentation and recomposition.

In each of these appearances, the word has a new form, a different signification, sketches a different reality. Therefore, its unity is not morphological, semantic, or referential. The word exists solely to become one with the scene in which it surges up like a cry, a murmur, a commandment, a story. It owes its unity, on the one hand, to the fact 
that, from scene to scene, in spite of the diversity of the scenery, actors, and episodes, it is the same noise that runs throughout, the same sound sign that detaches itself from the melee and floats for an instant above the episode like its audible banner; and, on the other hand, to the fact that these scenes form a history, stringing themselves together in a meaningful way according to the necessities of our frog ancestors' existence. A word is a paradox, a miracle, the wonderful accident of a single sound that different people, for different reasons, intending different things, cause to resound throughout a history/story [histoire]. It is the improbable series of the die that lands with the same face up seven times in a row. It doesn't matter who speaks and, when they speak, what might be said and with what vocabulary: it is the same jangling that, implausibly, resounds.

"Here are the captured bastards": no doubt the war cry of our aquatic ancestors, roaring with victory. Right away the rumor of battle spreads: all around, the messengers recount the enemies' defeat and how they were seized in the dirty water; a murmur of frogs around the marsh, a rustling of the reeds on the evening of the battle, croaking anew. Then an order resounds; the preparations are hurried, the cages are opened and closed again, and when the captives pass by, the crowd bays, "In the dungeons [salle aux pris: prisoners' room], in the dungeons." But the starving, the greedy, the mean, and the merchants of the tadpole city are thinking instead of meat and of the market: other desires, other words, the same brouhaha: "the pricing room" [salle aux prix]. The vanquished are locked up in the murkiest region of the swamp; but what narrator, what vigilant frog, what old scribe of grass and water, which of today's thinkers even, advanced enough in the timeless science of God, notes dreamily that the water there is dirty [sale eau] and that we hurl slops [saloperies] at the captives? Nevertheless, at the prison bars the crowd slob- bers and cries out, "Bastards!" [salauds]. And there, hovering over these multiple invectives, these motley scenes crossed by cries of war, is the great winged form of filth itself, majestic, relentless, and black: the unique sound. The filth of wars, of victories in the mud. The filth of the festive crowd heckling its captives. The filth of prisons. Filth of rewards dished out, of markets selling human flesh. What makes the essence of the word, its form and its meaning, its body and its soul, is this same noise throughout, always this same noise.

When dreamers go in search of the origins of language, they always ask themselves at what moment the first phoneme finally extracted itself from noise, introducing, with one fell swoop once and for all, beyond things and gestures, the pure order of the symbolic. Brisset's mania, by contrast, is to recount how discourse taken from scenes, from struggles, from the incessant game of hunger and violence little by little came to form this great repetitive noise that is the word, in flesh and bone. The word does not appear when the noise stops; it is born, with a shapely form, with all its various senses, when these discourses have sedimented and crumpled, smashing into one another within the sculptural outline of rustling. Brisset has invented the definition of the word by theatrical homophony.

\section{The Flight of Ideas}

Like Roussel, like Wolfson, Brisset is a systematic practitioner of the approximation [l'à-peu-près]. But the important thing is to grasp where and how he plays at this punning.

Roussel used two procedures successively. The first consists of taking a sentence, or some element of a phrase, then repeating it identically except for a slight slip, thereby establishing a distance between the two wordings in which an entire narrative will be propelled. The other consists of taking a fragment of text, whatever chance throws up, 
and by a chain of repetitive transformations extracting an entirely different series of heterogeneous motifs from it, with no semantic or syntactic link between them. The game is then to sketch out a story that, as an obligatory step, passes through each of the words thus obtained. Just as it was for Brisset, the starting point for Roussel is an utterance spoken anonymously or happened on by chance; in both, in the interstices of quasisimilarity, there is a series of apparitions of marvelous scenes by which the words become flesh. But Roussel brings forth his dwarfs, his rails made of calves' lungs, his cadaverous automatons, in the space-strangely empty and difficult to fill-opened up by an almost imperceptible wound at the heart of an arbitrary phrase. The rupture of a phonological difference (between $p$ and $b$, for example) does not produce, for him, a simple distinction in sense but rather an almost uncrossable chasm, which can only be bridged by an entire narrative; and when we stand on one edge of the divide and step out toward the other, it is by no means certain that the story will really get to the other side, so close, so similar. Brisset, by contrast, jumps, in an instant quicker than any thought, from one word to the next: bastard, dirty water, trophy room, prisoners' cell, filth; and, each time, the least of these tiny bounds, which barely change the sound, makes a new stage set appear in all its color: a battle, a swamp, the butchered prisoners, a cannibal marketplace. Around the sound, which remains as close as possible to its axis of identity, the scenes revolve as if on the rim of a great wheel; and thus, as each is called in turn by nearly identical cries, and charged to justify and somehow to present itself, they form, in an absolutely equivocal manner, a history [histoire] of words (induced in each of its episodes by the lightness, the inaudible sliding from one word to the other) and the story [histoire] of these words (the series of scenes, from which the noises were born, rose up, then froze to form words).
Wolfson's approximations are a means of turning one's own language inside out as one might the finger of a glove; of passing to the other side at the moment language comes at you, just when it is going to envelop you, overrun you, force-feed itself to you, fill you with evil and noisy objects that resound in your head for ages. It is a means of suddenly finding oneself on the outside, beyond the fatherland (or perhaps we should say motherland), hearing at last a neutralized language. His approximations provide a semantic protrusion, at the fleeting instant of sonic contact, between the maternal language, which must be neither spoken nor heard (even as it besieges you on all sides), and the smooth calmness of foreign languages, finally disarmed. Thanks to these rope bridges slung between one language and another and cunningly calculated in advance, the flight may be instantaneous, and the student of psychotic language is barely assailed by the furious idiom of his mother before making his retreat into the foreign, no longer hearing anything but soothing words. Brisset's operation is the opposite: around any word of his language as dull as can be found in the dictionary, he convenes, with great alliterative cries, other words, each trailing behind it the immemorial scenes of desire, war, savagery, devastation-or the little clamoring of demons and frogs, hopping on the banks of swamps. He undertakes to restore words to the noise that gave them birth and to restage the movements, the assaults, the violences of which they form a now-silent blazon: returning the Thesaurus linguae gallicae to primordial din, retransforming words into theater, putting sounds back into croaking throats, mixing them again with all the shreds of torn and devoured flesh, raising them up as a terrible dream, and forcing men to bow down once more: "All words started off in the mouth; they had to be put there in a sensible form, before taking on a spiritual form. We know that our ancestor initially intended to present us not with something to eat 
but with something to adore, a holy object, a pious relic that was his sex, tormenting him."

I do not know if psychiatrists would recognize in Brisset's vertiginous swirls what they traditionally call the "flight of ideas." In any case, I do not think we can analyze Brisset the same way they analyze that symptom: thought, they say, captivated solely by the acoustic material of language-forgetting meaning and losing the rhetorical continuity of speech-leaps, by the intermediary of a repeated syllable, from one word to another, letting this whole sonorous jangling spool out like a broken machine. Brisset-and no doubt others to whom we attribute this symptomdoes the opposite: for him, phonetic repetition does not represent a total liberation of language from its correspondence with things, thoughts, and bodies; it does not reveal speech in a state of absolute weightlessness. On the contrary, it sinks syllables into bodies, giving them back their functions as cries and gestures; it finds again the great plastic power of vociferation and gesticulation; it puts words back into the mouth and around the sex organs; quicker than all thought, it brings into being and effaces a whirlwind of frenetic scenes, savage or jubilant, from which words arise and that words call forth: these are the many Evohe of the Bacchanalia. ${ }^{4}$ Rather than one flight of ideas coming from a verbal iteration, we are dealing with an indefinitely accelerated phonetic scenography.

\section{The Three Procedures}

As Deleuze admirably puts it, "Psychosis and its language are inseparable from 'linguistic procedure,' from a linguistic procedure. In psychosis, the problem of procedure has replaced the problem of signification and repression" (preface to Louis Wolfson; Le schizo et les langues; Gallimard, 1970, p. 23). It comes into play when the relation between words and things is no longer one of designation, when the relation between one statement and another is no longer one of signification, when the relation between one language and another (or one state of language and another) is no longer one of translation. In the first instance, the procedure consists of a manipulation of the things embedded in words, not to separate them and restore to language its pure power of designation but to purify the things, to sanitize them, to discard all those charged with a harmful power: to stave off "the malignant, mad matter," as Wolfson calls it. The procedure is also that which, instead of uncovering an equivalence of signification, builds up, from one statement to another, close though they may be, a great thickness of speech, incidents, scenes, people, mechanisms, which bring about a material displacement by themselves: the Roussellian space of between-two-phrases. Finally, the procedure-and this is the absolute opposite of all translation-decomposes one state of language by means of another and from these ruins, from these fragments, from these still-red embers builds a stage on which to replay scenes of violence, murder, cannibalism. Thus, we find ourselves back with impure absorption. But we have come, not in a circle, but in a spiral: we are no longer at the same level we started out from. Wolfson feared the bad maternal object entering his body through the intermediary of words; Brisset stages the devouring of the human, clawed by words, reverting back to savagery.

Certainly, none of these three forms of procedure is entirely absent in Wolfson, Roussel, or Brisset. But each of them accords a privilege to one, depending on which aspect of language his suffering, his prudence, or his exultation has excluded in the first place. Wolfson suffers from the invasion of English words shot through with the hostile nourishment of the mother: to this language, which lacks the necessary distance for designation, the procedure responds instantly by closure (of body, of ears, of orifices: in short, by establishing a closed-off interiority) and by a 
movement to the exterior (into foreign languages toward which a thousand tiny underground channels have been dug); and from that little, well-sealed monad in which all foreign languages come to symbolize, Wolfson can no longer say anything but he. With the mouth sternly stoppered, the eyes greedily turn to books, absorbing every element that might be used by the well-established procedure to transform the maternal words into foreign terms at the point they enter the ear. We have the series: mouth, eye, ear.

Leaning over the breaches of language as if over the lens of a souvenir penholder, ${ }^{5}$ Roussel recognizes, between two almost identical expressions, such a rupture of signification that, to bring them together, he will have to pass them through the filter of their elementary sounds, to make them bounce several times, and to compose, out of these phonetic fragments, scenes whose subject matter, more than once, will be drawn from his own mouth: a crumb of bread, stuffed veal, teeth. Series: eye, ear, mouth.

As for Brisset, the ear leads the game from the moment the architectonics of the code collapses, rendering all translation impossible; repetitive noises spring up like elementary nuclei, and around them a whole whirligig of scenes appear and disappear, showing us their faces for less than an instant; in them, tirelessly, our ancestors devour one another.

When designation disappears so that things become imbricated with words, it is the mouth that is closed. When the communication of sentences through meaning breaks off, it is the eye that dilates before the infinity of difference. Finally, when the code is abolished, it is the ear that resounds with repetitive noises. I am saying not that code enters through the ear, while meaning enters through the eye and designation passes through the mouth (perhaps that's how Zeno saw it), but that the effacement of one of the dimensions of language corresponds to the arousal of a particular organ, an orifice that becomes excited, an element that is eroticized. From that erect organ to the other two, a mechanism is built-both a principle of domination and a procedure for transformation. At that time, the sites of languagemouth, eye, ear-start to work noisily in their primal materiality at the three vertices of the device revolving in our skull.

Lips sealed, decentered I, universal translation, the general symbolization of languages (to the exclusion of immediate speech, the mother tongue): this is Wolfson's vertex, the moment of knowledge formation. Eye dilated, the spectacle multiplying itself, wrapping around itself infinitely and foreclosed only to return to quasi-identity: this is Roussel's vertex, of dream and theater, of calm contemplation, of death mimed. Ear bristling, unstable repetitions, violence and appetites unleashed: this is Brisset's vertex, of intoxication and dance, of orgiastic gesticulation-the point at which poetry erupts and time is abolished again and again.

\section{What We Know about Brisset}

1. We know of seven publications by him:

La grammaire logique ou théorie d'une nouvelle analyse mathématique résolvant les questions les plus difficiles (Paris, 1878, $48 \mathrm{pp}$.)

La grammaire logique, résolvant toutes les difficultés et faisant connaitre par l'analyse de la parole la formation des langues et celle du genre humain (E. Leroux, 1883, 176 pp., 18mo)

Le mystère de Dieu est accompli (Angers, 1890, 176 pp., 18mo)

La science de Dieu, ou la création de l'homme (Chamuel, 1900, 252 pp., 18mo)

La grande nouvelle (Paris, 1900, 2 pp.)

Les prophéties accomplies: Daniel et l'Apocalypse (Angers, 1906, 299 pp., 18mo)

Les origines humaines, 2 nd ed. of La science de Dieu, completely revised (Angers, 1913, 244 pp., 18mo) 
2. Brisset was at one time a police officer. $\mathrm{He}$ gave lessons in modern languages. He would give his students dictations like this: "I, Paul Perfect, of the foot patrol, having been deployed to the village of Capeur, thus presented myself, dressed in full regalia."

3. He submitted La grammaire logique to the Académie Française for a competition. The work was rejected by the philosopher Ernest Renan.

4. It was after returning home one evening in June 1883 that he conceived Le mystère de Dieu.

5. On 29 July 1904 the newspaper Le petit parisien published an article entitled "Chez les fous" ["Among the Mad"]; it spoke of a madman "who claims to have based a whole metaphysical treatise, entitled La science de $\mathrm{Dieu}$, on a system of alliterations and farcical associations.... I haven't space to quote any passages from this maddening philosophy. Besides, reading them leaves one's mind in real turmoil. Readers will be grateful to me for wishing to spare them."

6. Brisset organized a lecture for 3 June 1906, drafting a program that stated, "The Archangel of the Resurrection and the Seventh Angel of the Apocalypse, which are one and the same, will make their voice heard and sound the trumpet of God through the mouth of the speaker. At this moment the Seventh Angel will empty his goblet in the air." Brisset had only fifty listeners. In his indignation he declared that henceforth none would hear the voice of the Seventh Angel.
7. Nevertheless, he would still write Les origines humaines, beginning its introduction thus: "Firstly I shall show that I have exercised all my might and spoken with a voice of thunder."

\section{TRANSLATOR'S NOTES}

1. In 1866 the Société de Linguistique de Paris issued a set of statutes declaring that it would no longer accept any communication concerning either the origin of language or the creation of a universal language.

2. Antoine Court de Gébelin (1725-84); his Histoire naturelle de la parole, ou précis de l'origine du langage et de la grammaire universelle (1776; Natural History of Speech; or, An Account of the Origin of Language and Universal Grammar) argued that all the languages of the world developed out of the same limited set of original signifying elements.

3. Like Court de Gébelin, Claude Duret (1570-1611) and Charles de Brosses (1709-77) published works on the origin and evolution of language: Thrésor de l'histoire des langues de cest univers (1613; Treasury of the History of the Languages of This World) and Traité de la formation mécanique des langues et des principes physiques de l'étymologie (1765; Treatise on the Mechanical Formation of Languages and the Physical Principals of Etymology), respectively.

4. Evohe was the cry used by revelers in the ancient Bacchic rites.

5. Roussel's long poem La vue (E. Lemerre, 1904; The View) describes in impossible detail the scene depicted underneath a lens set into a penholder. This type of miniature was a common souvenir of the period. 